Karolina KosSAKowSKa

Uniwersytet Łódzki

Wydział Nauk o Wychowaniu

Instytut Psychologii

Zakład Psychopatologii i Psychologii Klinicznej

91-433 Łódź, ul. Smugowa 10/12

e-mail:k.kossakowska@gmail.com

\title{
CHARAKTERYSTYKA I OCENA WLAŚCIWOŚCI PSYCHOMETRYCZNYCH POLSKIEJ ADAPTACJI SKALI POCZUCIA KOMPETENCJI RODZICIELSKICH (PARENTING SENSE OF COMPETENCE SCALE - PSOC-PL) W WERSJI DLA MATEK
}

\begin{abstract}
Abstrakt. Celem opracowania jest ocena właściwości psychometrycznych polskiej wersji Skali Poczucia Kompetencji Rodzicielskich (Parenting Sense of Competence Scale - PSOC-PL) Johnson i Masha do pomiaru kompetencji rodzicielskich u matek dzieci do 2. roku życia.

Parenting Sense of Competence Scale jest narzędziem samoopisu. Zawiera 17 twierdzeń składających się na wynik ogólny oraz dwa wymiary: Satysfakcja i Skuteczność. Służy do oceny kompetencji rodzicielskich.

W badaniach adaptacyjnych wzięło udział 251 kobiet mających dzieci w wieku do 24. miesiąca życia. Średni wiek badanych to 29,35 lat $(\mathrm{SD}=4,57)$. Dodatkowo do oceny trafności polskiej wersji adaptowanego narzędzia wykorzystano Kwestionariusz Poczucia Stresu i Edynburską Skalę Depresji Poporodowej.

PSOC-PL jest rzetelnym i trafnym narzędziem. Jego struktura czynnikowa jest podobna do wersji oryginalnej - w efekcie przeprowadzonej analizy uzyskano narzędzie, które składa się z 15 itemów. Tak jak w wersji oryginalnej, wyodrębnione zostały dwa wymiary: Satysfakcja i Skuteczność. Wyniki przy użyciu PSOC-PL uzyskane w prezentowanych badaniach pozostawały $\mathrm{w}$ istotnych statystycznie korelacjach z poziomem stresu i nasileniem objawów depresyjnych.

Rezultaty rzetelności PSOC-PL nie odbiegają od wyników uzyskanych w badaniach oryginalnych, jak i w badaniach ewaluacyjnych prowadzonych w różnych częściach świata. Polska wersja narzędzia spełnia podstawowe kryteria psychometryczne i może być stosowana do oceny kompetencji u matek małych dzieci.
\end{abstract}

Słowa kluczowe: kompetencje rodzicielskie, skuteczność, satysfakcja, walidacja, PSOC - wersja polska. 


\section{WSTĘP}

Adaptacja do macierzyństwa jest procesem złożonym, obejmującym różnorodne aspekty funkcjonowania związane z rolą rodzica. Nie ulega wątpliwości, że jakość i sposób opieki nad dzieckiem we wczesnym okresie życia odgrywa kluczową rolę dla jego rozwoju, tak w sferze społecznej i emocjonalnej, jak poznawczej i intelektualnej (Czub, 2003). Wśród czynników istotnych dla interakcji pomiędzy matką a dzieckiem, które staną się podwaliną więzi w stosunku do dziecka oraz przywiązania z jego strony, wymienić należy poczucie satysfakcji i skuteczności. Jedno i drugie uznawane są za istotne kompetencje w pełnieniu nowej roli. Zarówno obecność, jak i brak satysfakcji i/lub skuteczności w opiece nad dzieckiem, zwłaszcza małym, determinować może zachowania matki i późniejsze trudności w radzeniu sobie z wyzwaniami macierzyństwa.

Podejmując się zdefiniowania pojęcia satysfakcja z macierzyństwa, warto odwołać się do pojęcia ogólnej satysfakcji z życia, która w literaturze często określana jest również jako zadowolenie z życia, jakość życia lub dobrostan, a nawet szczęście (za: Walęcka-Matyja, Kurpiel, 2015). Każde z tych ujęć satysfakcji z życia możemy z powodzeniem odnieść do satysfakcji z macierzyństwa. Według Argyle’a (2004) zadowolenie z życia jest tożsame ze szczęściem i oznacza częstość i intensywność doświadczania przyjemnych emocji. Satysfakcja z macierzyństwa w tym ujęciu mogłaby zatem odnosić się do doświadczania pozytywnych emocji związanych z pełnieniem roli matki. Podobnie ma się rzecz, jeśli odwołamy się do ujęcia zadowolenia z życia autorstwa Ruut Veenhovena (1991), według którego oznacza ono stopień, w jakim jednostka ocenia pozytywnie całościowo swoje życie. Satysfakcja/ zadowolenie z macierzyństwa miałaby się odnosić do stopnia pozytywnej oceny ogólnej macierzyństwa. Zygfryd Juczyński (2001), podążając za ujęciem Dienera (Diener, Lucas, Oishi, 2002), traktuje satysfakcję z życia jako efekt świadomego poznawczego porównywania własnej sytuacji z określonymi przez jednostkę standardami. Jak łatwo wywnioskować, im bardziej zadowalający jest wynik takiego porównania, tym większa satysfakcja. O satysfakcji z macierzyństwa w nawiązaniu do tej definicji będziemy mówić wówczas, gdy kobieta ocenia pozytywnie to, jak radzi sobie w roli matki w odniesieniu np. do jej wcześniejszych oczekiwań czy wyobrażeń. W zbliżony sposób mówi o zadowoleniu z życia Janusz Czapiński (2004) - jest to jego zdaniem emocjonalny i poznawczy bilans życia oceniany w sposób wartościujący, np. dobre - złe. Zadowolenie z macierzyństwa mogłoby w tym przypadku również być oceniane w wymiarze wartościującym.

Poczucie skuteczności własnej (ang. self-efficacy) to pojęcie wprowadzone przez Alberta Bandurę $(1977,1997)$, który stwierdził, że na poczucie własnej skuteczności składa się ocena przez osobę tego, w jakim stopniu jest ona w stanie radzić sobie z bieżącymi lub potencjalnymi wyzwaniami. Wynik tej oceny miałby determinować podejmowane działania (lub ich brak). Inaczej mówiąc - poczucie własnej skuteczności wpływa pozytywnie na motywację do działania. Podobnego 
zdania są Locke i Latham (1990, za: Juczyński, 2000), którzy twierdzą, że silniejsze przekonania na temat własnej skuteczności u danej osoby wpływają na stawianie sobie wyższych celów i silniejsze zaangażowanie w zamierzone zachowanie, nawet jeśli w trakcie realizacji tego zadania osoba ta doświadcza porażek. Zatem poczucie własnej skuteczności odnoszące się do macierzyństwa możemy rozumieć jako kompetencje matki umożliwiające jej radzenie sobie z wyzwaniami, jakie to macierzyństwo niesie.

Dotychczasowe badania podejmujące problematykę skuteczności związanej z pełnieniem roli rodzica wskazują na silne związki poczucia skuteczności z poziomem stresu u rodziców - niskiemu poczuciu skuteczności towarzyszy wysoki poziom stresu i depresji i odwrotnie (Jackson, 2000; Raikes, Thompson, 2005). Zwraca się też uwagę na protekcyjne znaczenie poczucia skuteczności własnej rodzica dla prawidłowego rozwoju dziecka (Shumow, Lomax, 2002; Jones, Prinz, 2005) oraz na pozytywny związek poczucia skuteczności rodzica z adaptacyjnymi zachowaniami u dziecka (Coleman, Karraker, 2000). Kiedy bowiem matka lub ojciec czują się pewni w swoim macierzyństwie lub ojcostwie, jest bardziej prawdopodobne, że będą podejmować takie działania, które przynoszą dziecku korzyści rozwojowe. Z badań Jackson (2000) wynika, że matki z wyższym poziomem poczucia własnej skuteczności miały większe kompetencje rodzicielskie niż te, u których poziom poczucia własnej skuteczności był niski.

Ponieważ poczucie skuteczności własnej rodziców jest czynnikiem tak ważnym dla ich dobrostanu psychicznego, relacji z dzieckiem i przebiegu jego dalszego rozwoju, możliwość jego pomiaru wydaje się istotna w kontekście oceny zasobów, jak i potencjalnych trudności, jakich doświadczają rodzice w opiece nad dzieckiem. Z przeglądu przeprowadzonego przez Jones i Prinz (2005) wynika, że najczęściej stosowanym narzędziem do pomiaru poczucia własnej skuteczności u rodziców jest skala Parenting Sense of Competence (PSOC) (Gibaud-Wallston, Wandersman, 1978; Johnston, Mash 1989). Podstawę teoretyczną narzędzia stanowiło poczucie własnej wartości u rodziców (parenting self-esteem), na które składają się poczucie skuteczności własnej rodziców oraz satysfakcja płynąca z bycia rodzicem. Johnston i Mash (1989) w definiowaniu własnej skuteczności w kontekście pełnienia roli rodzicielskiej odwołują się do wspomnianej wcześniej koncepcji Bandury (1982, za: Johnston, Mash, 1989), która opisuje ją jako stopień, w jakim rodzic czuje się kompetentny w radzeniu sobie z problemami związanymi z opieką i wychowaniem dziecka.

Liczące już 40 lat narzędzie w kolejnych badaniach wykorzystywane było do oceny rodzicielskiego poczucia skuteczności, własnej wartości czy ogólnie kompetencji rodzicielskich w różnych grupach rodziców - m.in. rodziców nastolatków (Gilmore, Cuskelly, 2009), rodziców z grupy ryzyka (Nunez i in., 2014). Jednak aż do 2015 roku nie odnotowano użycia go w badaniach z udziałem rodziców niemowląt i małych dzieci, a w szczególności matek. Dopiero zespół Karp, Lutenbacher i Wallston (2015) podjął się walidacji narzędzia właśnie w odniesieniu 
do matek małych dzieci. Podczas gdy poczucie satysfakcji z macierzyństwa i skuteczności w realizowaniu roli matki w pierwszych latach życia dziecka wiąże się z wieloma specyficznymi tylko dla tego okresu i dla tej relacji wyzwaniami, zasadna wydaje się adaptacja narzędzia z udziałem grupy homogenicznej składającej się wyłącznie z kobiet-matek małych dzieci.

\section{CEL}

Celem prezentowanych badań było opracowanie polskiej adaptacji Parenting Sense of Competence Scale w wersji dla matek małych dzieci oraz oszacowanie jego przydatności poprzez psychometryczną ewaluację. Badania stanowiły część większego projektu i były realizowane w ramach grantu wydziałowego $\mathrm{nr}$ 545/734.

\section{METODA}

\subsection{PSOC - charakterystyka narzędzia}

Parenting Sense of Competence Scale (PSOC) to narzędzie, które zaprojektowane zostało przez zespół Gibaud-Wallston i Wandersman (1978) do oceny przez rodziców ich zdolności (kompetencji) rodzicielskich.

W pierwszej, oryginalnej wersji PSOC autorzy w twierdzeniach kwestionariusza użyli pojęcia „niemowlę” (ang. infant), wyraźnie zaznaczając tym samym, że narzędzie skierowane jest do rodziców dzieci od 1. miesiąca do ok. 1. roku życia (Gibaud-Wallston, 1977). Zgodnie z założeniami ocena właściwości psychometrycznych oryginalnego narzędzia została przeprowadzona $\mathrm{z}$ udziałem 56 par kobiet i mężczyzn, którzy po raz pierwszy zostali rodzicami, a średni wiek ich dzieci wynosił 11 miesięcy. PSOC zawierał 17 twierdzeń składających się na wynik ogólny oraz dwa wymiary: Skill/Knowledge ( 8 twierdzeń służących ocenie, w jakim stopniu w percepcji rodziców posiadają oni umiejętności i wiedzę potrzebną do bycia dobrym rodzicem) oraz Valuing/Comfort ( 9 twierdzeń odnoszących się do stopnia, w jakim oceniają indywidualną wartość bycia rodzicem i na ile czują się dobrze w tej roli). Współczynniki rzetelności wyniosły kolejno $0,80,0,80$ i 0,69 .

Wykorzystywana obecnie w licznych badaniach Parenting Sense of Competence Scale to wersja zrewidowana przez Johnston i Masha (1989). Autorzy ci dokonali ewaluacji psychometrycznej oryginalnego narzędzia $\mathrm{w}$ badaniach $\mathrm{z}$ udziałem rodziców dzieci w wieku przedszkolnym i wczesnoszkolnym (4-9 lat). Na tej podstawie opracowali wersję do pomiaru kompetencji rodzicielskich u rodziców starszych dzieci, niż miało to miejsce w badaniach oryginalnych. Wprowadzili 
W związku $\mathrm{z}$ tym zmianę $\mathrm{w}$ twierdzeniach polegającą na zamianie terminu niemowlę (ang. infant lub bardziej potoczne określenie baby) na dziecko (ang. child). Podobnie jak w badaniach oryginalnych, analiza czynnikowa wyłoniła dwa wymiary, którym autorzy ostatecznej wersji narzędzia nadali inne, choć korespondujące z poprzednimi nazwy - wymiar Satysfakcja (ang. Satisfaction; odpowiednik Valuing/Comfort) i Skuteczność Wtasna (ang. Self-Efficacy; odpowiednik Skill/ Knowledge). Składa się na nie kolejno 9 i 7 twierdzeń. Wynika to z usunięcia ostatniego (17.) itemu, który po zastosowaniu analizy czynnikowej metodą głównych składowych uzyskał bardzo niską wartość ładunku. Podobne rezultaty otrzymano także w innych badaniach (Nunez i in., 2014).

Trafność konwergencyjna narzędzia została potwierdzona w licznych badaniach dotyczących właściwości psychometrycznych narzędzia. Odnotowano m.in. silne korelacje wyników mierzonych za pomocą PSOC z wynikami w skalach do pomiaru ogólnego poczucia własnej skuteczności (Coleman, Karraker, 2000; Hess i in., 2002, za: Karp, 2015) oraz skalą do pomiaru skuteczności u matek Maternal Self-Efficacy Scale (Teti, Gelfand, 1991). Ponadto wyniki uzyskane przy użyciu skali korelują ujemnie z wynikami uzyskiwanymi w pomiarze zaburzeń nastroju (Kohlhoff, Barnett, 2013).

PSOC jest narzędziem samoopisowym, w skład którego wchodzi 17 twierdzeń ocenianych na 6-stopniowej skali Likerta (od 1 - całkowicie się nie zgadzam, do 6 - całkowicie się zgadzam). Podskala Satysfakcja (9 itemów) zawiera twierdzenia odnoszące się m.in. do przeżywania frustracji przez rodzica, niepewności czy napięcia (np. „Chociaż bycie rodzicem/matka/ojcem może być satysfakcjonujace, w obecnej chwili jestem sfrustrowana/y”, „Problem w byciu rodzicem/ matka/ojcem polega na tym, że nie wiesz, czy to, co robisz, jest dobre czy nie"). Podskala ta ma odwrócony klucz, a zatem brak zgody z twierdzeniem wskazuje na większą satysfakcję w byciu rodzicem. Podskala Skuteczność Własna (7 itemów) obejmuje twierdzenia związane m.in. z umiejętnością rozwiązywania problemów dotyczących dziecka, czy przekonaniem, że daję sobie radę jako rodzic (np. „Problemy zwiqzane z opieka nad dzieckiem sq łatwe do rozwiazania, gdy wiesz, jak twoje działania wptywaja na dziecko”, „Jeśli ktoś wie, co trapi moje dziecko, to jestem to ja"). Zgoda z twierdzeniami oznacza wysokie poczucie własnej skuteczności w roli rodzica. Narzędzie pozwala również na obliczenie wyniku ogólnego, na który składają się wyniki z obu podskal. Im wyższy wynik, tym wyższe ogólne poczucie kompetencji rodzicielskich.

Autorzy wersji oryginalnej, po zaprezentowaniu narzędzia na konferencji, nie opublikowali raportu z badań nad jego psychometrycznymi właściwościami i zaprzestali dalszych prac nad jego walidacją. W chwili obecnej osobami dysponującymi kwestionariuszem są Charlotta Johnston i John Mash i to ich zgodę uzyskano przed przystąpieniem do pracy nad polskojęzyczną wersją PSOC. W prezentowanych badaniach wykorzystano oryginalną 17-itemową wersję kwestionariusza. 


\subsection{PSOC-PL - praca nad polską wersją językową}

Badania nad opracowaniem polskiej wersji językowej Parenting Sense of Competence Scale (PSOC-PL) oraz ocena psychometrycznych właściwości narzędzia miały miejsce w latach 2015-2016.

W pierwszym etapie dwujęzyczny thumacz dokonał przekładu oryginalnych twierdzeń z języka angielskiego na polski. Następnie powołano zespół kompetentnych sędziów, składający się z trzech matek dzieci do 2 r.ż. oraz psychologa. Dobór sędziów był celowy ze względu na kryteria - posiadanie dzieci do 2 r.ż. (matki małych dzieci) oraz wykształcenie wyższe i wiedza merytoryczna z zakresu psychologii rozwojowej i wychowawczej (psycholog). Sędziowie przeanalizowali poszczególne twierdzenia w celu wyłonienia ewentualnych niejasności. Sędziowie kompetentni zgodzili się co do tego, że w języku polskim funkcjonuje wprawdzie termin „niemowlę”, jednak określamy nim dziecko do 1. roku życia, brakuje natomiast odpowiednika angielskiego „baby”, które występowało w wersji anglojęzycznej adresowanej do rodziców najmłodszych dzieci. Zadecydowano zatem, że termin „dziecko” jako uniwersalny może z powodzeniem zostać wykorzystany w polskojęzycznej wersji narzędzia, niezależnie od tego, w jakim wieku będą dzieci badanych tym narzędziem rodziców.

Po wprowadzeniu drobnych poprawek polska wersja narzędzia została przetłumaczona ponownie na język angielski (back translation). W ostatnim etapie porównano obie wersje anglojęzyczne, przeanalizowano różnice i ustalono ostatecznie polską wersję językową PSOC, nadając jej nazwę Skala Poczucia Kompetencji Rodzicielskich - PSOC-PL.

\subsection{Uczestnicy}

W badaniach adaptacyjnych udział wzięło 251 matek dzieci do 2 r.ż. Badane były w wieku od 19 do 43 lat $(M=29,32 ; S D=4,65)$. Przeważającą większość stanowiły zamężne $(77,7 \%)$, mieszkanki dużych miast (58\%), z wyższym wykształceniem (74\%), które zostały matkami po raz pierwszy (69\%). Szczegółową charakterystykę socjodemograficzną grupy badanej przestawia tabela 1 .

Tabela 1. Charakterystyka socjodemograficzna badanej grupy

\begin{tabular}{|c|c|c|}
\hline Charakterystyka & $\mathrm{N}$ & $\mathrm{n}(\%)$ \\
\hline \multicolumn{3}{|c|}{ Sytuacja życiowa } \\
\hline W związku małżeńskim & 195 & 77,7 \\
\hline W związku partnerskim & 49 & 19,5 \\
\hline Samotnie wychowująca dziecko & 7 & 2,8 \\
\hline
\end{tabular}




\begin{tabular}{|c|c|c|}
\hline \multicolumn{3}{|c|}{ Wykształcenie } \\
\hline Wyższe & 186 & 74,1 \\
\hline Zawodowe & 5 & 2,0 \\
\hline Średnie & 37 & 14,7 \\
\hline Policealne & 18 & 7,2 \\
\hline Podstawowe & 5 & 2,0 \\
\hline \multicolumn{3}{|c|}{ Miejsce zamieszkania } \\
\hline Duże miasto (powyżej 100 tys.) & 147 & 58,6 \\
\hline Małe miasto (poniżej 100 tys.) & 66 & 26,3 \\
\hline Wieś & 38 & 15,1 \\
\hline \multicolumn{3}{|c|}{ Sytuacja finansowa } \\
\hline Bardzo dobra & 46 & 18,3 \\
\hline Dobra & 183 & 72,9 \\
\hline Zła & 20 & 8,0 \\
\hline Bardzo zła & 2 & 0,8 \\
\hline \multicolumn{3}{|c|}{ Liczba posiadanych dzieci } \\
\hline Jedno & 175 & 69,7 \\
\hline Dwoje & 65 & 25,9 \\
\hline Troje & 7 & 2,8 \\
\hline Czworo & 3 & 1,2 \\
\hline Pięcioro i więcej & 1 & 0,4 \\
\hline
\end{tabular}

Źródło: opracowanie własne.

\subsection{Procedura}

Kryterium doboru do próby był minimalny wiek w momencie przystąpienia do badania - 19. rok życia (kryterium, które ma na celu wykluczenie z udziału w badaniach kobiet, które zaszły w ciążę jako nieletnie) oraz wiek dziecka - nieprzekroczony 2. rok życia. W badaniach wzięły udział kobiety, które odpowiedziały na ogłoszenie zamieszczone na stronach internetowych poświęconych macierzyństwu i rodzicielstwu lub pozyskane za pomocą kontaktów społecznych.

Badane wypełniały zestaw kwestionariuszy, który wraz z instrukcją został im dostarczony osobiście lub przesłany pocztą. Udział w badaniach był dobrowolny, uczestniczki wyraziły świadomą zgodę na udział i zostały poinformowane o przeznaczeniu wyników badań wyłącznie do celów naukowych. 


\subsection{Narzędzia}

W badaniach wykorzystano:

- ankietę własnej konstrukcji, służącą zebraniu danych socjodemograficznych (m.in. wiek, wykształcenie, stan cywilny, miejsce zamieszkania) oraz informacji związanych z dzieckiem (m.in. płeć dziecka, czas od porodu, inne dzieci);

- 17-itemową polską wersję językową Skali Poczucia Kompetencji Rodzicielskich (PSOC-PL) (Johnston, Mash, 1989) - do oceny satysfakcji i poczucia własnej skuteczności, z uwzględnieniem m.in. poziomu frustracji przeżywanej przez matkę oraz skuteczności w rozwiązywaniu problemów.

W zestawie kwestionariuszy, które wypełniły badane kobiety, znalazły się także:

- Kwestionariusz Poczucia Stresu (KPS) (Plopa, Makarowski, 2010) - służący do pomiaru struktury doznań stresowych. KPS pozwala na obliczenie wyniku ogólnego, informującego o uogólnionym poziomie stresu, a także trzech wyników odnoszących się do następujących wymiarów: napięcie emocjonalne, stres zewnętrzny oraz stres intrapsychiczny. Wykorzystanie KPS w badaniach adaptacyjnych służyło określeniu trafności konwergencyjnej polskiej wersji. Wcześniejsze badania zwróciły bowiem uwagę, że kompetencje rodzicielskie są istotnie powiązane z poziomem doświadczanego przez rodziców stresu (Begle, Dumas, 2011; Bloomfield, Kendall, 2012). W prezentowanych badaniach zastosowano jedynie pomiar wyniku ogólnego.

- Edynburska Skala Depresji Poporodowej (EPDS) (Cox, Holden, Sagovsky, 1987) - zastosowana w celu pomiaru nasilenia symptomów depresyjnych u badanych matek. EPDS jest krótką skalą - składa się z 10 twierdzeń opisujących różne aspekty samopoczucia kobiety, m.in. anhedonia, poczucie winy, smutek i przygnębienie czy płaczliwość (Beck, Indman, 2005), jednak twierdzenia są skonstruowane tak, że nie odnoszą się bezpośrednio do okoliczności związanych z porodem i połogiem (np. „Mogłam się śmiać i bytam zdolna zauważać zabawne strony tego, co się dzieje”, „Gdy coś złego się wydarzyło, uważałam, że to moja wina” lub „Byłam smutna lub czułam się przygnębiona”). Skala, podobnie jak KPS, została użyta w celu określenia związku objawów depresyjnych z wynikami uzyskanymi PSOC-PL. Wcześniejsze badania wskazują na korelację ujemną pomiędzy tymi zmiennymi (Caldwell i in., 2011; Kohlhoff, Barnett, 2013).

\subsection{Analiza statystyczna}

Uzyskane dane poddano analizie statystycznej za pomocą pakietu statystycznego PS IMAGO 24. Wykorzystując test Shapiro-Wilka, sprawdzono normalność rozkładów dla analizowanych zmiennych. Rozkład zbliżony do normalnego potwierdzono dla wyniku ogólnego i podskal Satysfakcja oraz Skuteczność w Skali Poczucia Kompetencji Rodzicielskich. Dla wyników mierzonych za pomocą 
EPDS i KPS odnotowano brak normalności rozkładu. Zastosowano statystyki opisowe, współczynnik alfa Cronbacha, eksploracyjną analizę czynnikową (rotacja Varimax z normalizacją Kaisera) i współczynnik korelacji r-Pearsona oraz rho-Spearmana. $\mathrm{W}$ trakcie analizy przyjęto poziom istotności testów $\alpha=0,05$.

\section{WYNIKI}

\subsection{Rozkład wyników}

Prace nad psychometryczną oceną polskiej wersji narzędzia rozpoczęto od ustalenia podstawowych danych dotyczących rozkładu wyników. Średnia dla całego narzędzia wyniosła 67,35 przy odchyleniu standardowym równym 10,50 . Średnia dla podskali Satysfakcja wyniosła 37,82 (SD =6,86), a dla skali Skuteczność 29,53 (SD = 5,12). Wyniki w obu podskalach korelowały ze sobą dodatnio na poziomie istotności statystycznej - współczynnik korelacji r-Pearsona wyniósł $r(251)=0,528, \mathrm{p}<0,01$.

\subsection{Rzetelność}

Rzetelność PSOC-PL została oceniona za pomocą analizy właściwości statystycznych pozycji testowych. Współczynnik rzetelności alfa Cronbacha dla całego narzędzia wyniósł 0,837 , przekraczając rekomendowaną wartość 0,7 i wskazując na rzetelność PSOC dla badanej próby. W przypadku podskal współczynniki rzetelności były jednak niższe - dla podskali Satysfakcja alfa Cronbacha wyniósł 0,785 , podczas gdy dla podskali Skuteczność nieznacznie mniej od rekomendowanej wartości, czyli 0,699. Należy jednak zwrócić uwagę, że uzyskane na polskiej próbie wyniki nie odbiegają od wyników uzyskanych w badaniach oryginalnych (kolejno: 0,80, 0,80 i 0,69) (Gibaud-Wallston, Wandersman, 1978) i są wyższe niż w portugalskich badaniach adaptacyjnych (wynik ogólny - brak danych, podskale kolejno: 0,69 i 0,65) (Nunez i in., 2014).

Średnia korelacja pomiędzy pozycjami testowymi wyniosła 0,24 , z wartością minimalną równą $-0,09$ i maksymalną równą 0,57 . Korelacja wyników pozycji testowych $\mathrm{z}$ ogólnym wynikiem testowym przekroczyła rekomendowany punkt graniczny dla 15 z 17 pozycji, żadna z nich nie kwalifikuje się zatem do usunięcia. Jedynie twierdzenie nr 1 (,Problemy zwiqzane z opieka nad dzieckiem sq tatwe do rozwiazania, gdy wiesz, jak twoje działania wpływaja na dziecko") oraz twierdzenie nr 12 (,Moje zdolności i zainteresowania nie sa związane z byciem matka") koreluje z ogólnym wynikiem skali na poziomie poniżej 0,3 . Korelacje przedstawia tabela 2 . 
Tabela 2. Wyniki korelacji pozycji testowych z ogólnym wynikiem skali

\begin{tabular}{|c|c|c|c|}
\hline $\begin{array}{l}\text { Numer } \\
\text { twierdzenia }\end{array}$ & Treść twierdzenia & $\begin{array}{c}\text { Korelacja } \\
\text { z wynikiem } \\
\text { sumarycznym }\end{array}$ & $\begin{array}{l}\text { Współczynnik } \\
\text { alfa Cronbacha } \\
\text { po usunięciu } \\
\text { pozycji }\end{array}$ \\
\hline PSOC-PL 1 & $\begin{array}{l}\text { Problemy związane z opieką nad dzieckiem } \\
\text { są łatwe do rozwiązania, gdy wiesz, jak twoje } \\
\text { działania wpływają na dziecko }\end{array}$ & 0,059 & 0,853 \\
\hline PSOC-PL 2 & $\begin{array}{l}\text { Chociaż bycie matką może być } \\
\text { satysfakcjonujące, w obecnej chwili jestem } \\
\text { sfrustrowana }\end{array}$ & 0,588 & 0,820 \\
\hline PSOC-PL 3 & $\begin{array}{l}\text { Chodzę spać i budzę się z tym samym uczuciem } \\
\text { braku dokonania czegokolwiek }\end{array}$ & 0,611 & 0,819 \\
\hline PSOC-PL 4 & $\begin{array}{l}\text { Nie rozumiem dlaczego, ale czasem, gdy } \\
\text { próbuję panować nad sobą, czuję jakby ktoś mną } \\
\text { manipulował }\end{array}$ & 0,506 & 0,825 \\
\hline PSOC-PL 5 & $\begin{array}{l}\text { Moja matka była lepiej przygotowana do bycia } \\
\text { dobrą matką niż ja }\end{array}$ & 0,406 & 0,831 \\
\hline PSOC-PL 6 & $\begin{array}{l}\text { Byłabym niezłym wzorem do naśladowania dla } \\
\text { przyszłej matki, która chciałaby wiedzieć, co } \\
\text { należy robić, żeby być dobrym rodzicem }\end{array}$ & 0,515 & 0,826 \\
\hline PSOC-PL 7 & $\begin{array}{l}\text { Bycie matką nie jest trudne, a wszystkie } \\
\text { problemy da się rozwiązać }\end{array}$ & 0,483 & 0,826 \\
\hline PSOC-PL 8 & $\begin{array}{l}\text { Problem w byciu rodzicem polega na tym, że nie } \\
\text { wiesz, czy to, co robisz, jest dobre czy nie }\end{array}$ & 0,348 & 0,834 \\
\hline PSOC-PL 9 & $\begin{array}{l}\text { Czasem czuję, że nie potrafię doprowadzić spraw } \\
\text { do końca }\end{array}$ & 0,404 & 0,831 \\
\hline PSOC-PL 10 & $\begin{array}{l}\text { Poprzez opiekę nad dzieckiem spełniam swoje } \\
\text { oczekiwania }\end{array}$ & 0,550 & 0,824 \\
\hline PSOC-PL 11 & $\begin{array}{l}\text { Jeśli ktoś wie, co trapi moje dziecko, to jestem } \\
\text { to ja }\end{array}$ & 0,392 & 0,831 \\
\hline PSOC-PL 12 & $\begin{array}{l}\text { Moje zdolności i zainteresowania nie są } \\
\text { związane z byciem matką }\end{array}$ & 0,209 & 0,841 \\
\hline PSOC-PL 13 & $\begin{array}{l}\text { Biorąc pod uwagę, jak długo jestem matką, czuję } \\
\text { się dobrze w tej roli }\end{array}$ & 0,576 & 0,822 \\
\hline PSOC-PL 14 & $\begin{array}{l}\text { Starałabym się być lepszym rodzicem, gdyby } \\
\text { bycie matką było bardziej interesujące }\end{array}$ & 0,450 & 0,829 \\
\hline PSOC-PL 15 & $\begin{array}{l}\text { Jestem przekonana, że posiadam wszystkie } \\
\text { umiejętności niezbędne do bycia dobrą matką }\end{array}$ & 0,439 & 0,829 \\
\hline PSOC-PL 16 & $\begin{array}{l}\text { Bycie matką sprawia, że jestem napięta } \\
\text { i niespokojna }\end{array}$ & 0,618 & 0,818 \\
\hline PSOC-PL 17 & Bycie dobrą matką jest nagrodą samą w sobie & 0,461 & 0,828 \\
\hline
\end{tabular}

Źródło: opracowanie własne. 
Dodatkowo dokonano oceny rzetelności narzędzia metodą test-retest. Przy użyciu polskojęzycznej wersji skali zbadano w odstępie dwóch tygodni 51 kobiet w wieku od 20. do 39. roku życia $(\mathrm{M}=29,35, \mathrm{SD}=4,49)$. Otrzymany współczynnik korelacji dla wyników ogólnych $\mathrm{r}_{\mathrm{tt}}=0,99, \mathrm{p}<0,001$ wskazuje na wysoką stabilność czasową narzędzia. Współczynniki dla podskali Satysfakcja i Skuteczność wyniosły kolejno: $\mathrm{r}_{\mathrm{tt}}=0,98, \mathrm{p}<0,001 \mathrm{i}_{\mathrm{tt}}=0,96, \mathrm{p}<0,001$.

Zastosowano także test t-Studenta dla prób zależnych w celu porównania wyników uzyskanych przy użyciu PSOC z pierwszego i drugiego pomiaru. Wyniki ogólne oraz w podskalach z pierwszego pomiaru różnią się istotnie od tych, które uzyskano w pomiarze drugim. Wyniki przedstawia tabela 3.

Tabela 3. Porównanie średnich dla wyniku ogólnego i podskal w pierwszym i drugim pomiarze

\begin{tabular}{|l|c|c|c|c|c|c|}
\hline & \multicolumn{2}{|c|}{$\begin{array}{c}\text { Pomiar pierwszy } \\
(\mathrm{n}=51)\end{array}$} & \multicolumn{2}{c|}{$\begin{array}{c}\text { Pomiar drugi } \\
(\mathrm{n}=51)\end{array}$} & \multirow{2}{*}{$\mathrm{t}(\mathrm{df})$} & $\mathrm{p}$ \\
\cline { 2 - 5 } & $\mathrm{M}$ & $\mathrm{SD}$ & $\mathrm{M}$ & $\mathrm{SD}$ & & \\
\hline $\begin{array}{l}\text { PSOC-PL } \\
\text { wynik ogólny }\end{array}$ & 64,78 & 10,20 & 65,8 & 9,16 & $-4,336(50)$ & $<0,001$ \\
\hline $\begin{array}{l}\text { PSOC-PL } \\
\text { Satysfakcja }\end{array}$ & 34,39 & 6,59 & 34,76 & 5,91 & $-2,250(50)$ & 0,029 \\
\hline $\begin{array}{l}\text { PSOC-PL } \\
\text { Skuteczność }\end{array}$ & 30,39 & 5,69 & 31,04 & 5,07 & $-4,231(50)$ & $<0,001$ \\
\hline
\end{tabular}

Źródło: opracowanie własne.

\subsection{Trafność}

W celu określenia trafności teoretycznej i zweryfikowania struktury wewnętrznej skali zastosowano eksploracyjną analizę czynnikową (metoda głównych składowych, rotacja Varimax z normalizacją Kaisera). Przystępując do analizy czynnikowej, sprawdzono, czy otrzymane dane spełniają wymagane założenia. Współczynnik KMO wyniósł 0,86, natomiast test sferyczności Bartletta wyniósł $1150,68, \mathrm{p}<0,001$, a zatem otrzymane wskaźniki były zadowalające. Wyodrębniono składowe charakteryzujące się wartością własną powyżej 1 . Skumulowany odsetek wyjaśnianej wariancji wyniósł 53,00. Analiza czynnikowa doprowadziła do wyodrębnienia czterech czynników, z których pierwszy wyjaśniał 30,50\% wariancji, drugi $-8,76 \%$, trzeci $-7,12 \%$ i czwarty $-6,62 \%$.

Ponieważ jednak założenia teoretyczne sugerowały rozwiązanie dwuczynnikowe, ponownie przeprowadzono analizę czynnikową, decydując się na wyodrębnienie dwóch wymiarów, z uwzględnieniem ładunków czynnikowych z wartością bezwzględną powyżej 0,40 . Wymiary te wyjaśniały łącznie $39,26 \%$ wariancji. Wyodrębnione czynniki odpowiadają czynnikom w wersji oryginalnej. W skład 
czynnika pierwszego (Satysfakcja) weszły twierdzenia 2, 3, 4, 5, 8, 9, 14 i 16 (pozycje odwrócone), zaś w skład czynnika drugiego (Skuteczność) - twierdzenia 6, $7,10,11,13,15,17$. Są to zatem te same twierdzenia, które wchodzą w skład obu podskal w oryginalnej wersji narzędzia. Zmiana dotyczy jedynie braku twierdzeń nr 1 i nr 12 z wersji oryginalnej, które ze względu na niskie wartości ładunków czynnikowych zostały usunięte z polskiej wersji językowej skali. Należy podkreślić, że są to te same itemy, które korelowały z ogólnym wynikiem skali na poziomie poniżej 0,3 . W polskiej adaptacji narzędzia zachowane zostało z kolei twierdzenie $\mathrm{nr}$ 17, które $\mathrm{w}$ innych adaptacjach zazwyczaj usuwano z uwagi na niską wartość czynnikową. Twierdzenie na podstawie analizy czynnikowej zostało włączone do podskali Skuteczność. Ładunki czynnikowe (z zaznaczeniem ładunków o wartości powyżej 0,40 ) wraz z wartościami wyjaśnianej wariancji uzyskane dla rozwiązania dwuczynnikowego przedstawia tabela 4.

Tabela 4. Eksploracyjna analiza czynnikowa, metoda głównych składowych, z zastosowaniem rotacji Varimax - rozwiązanie dwuczynnikowe

\begin{tabular}{|c|c|c|}
\hline \multirow{2}{*}{ Twierdzenie } & \multicolumn{2}{|c|}{ Czynniki } \\
\hline & 1 & 2 \\
\hline PSOC-PL 3 & 0,754 & \\
\hline PSOC-PL 4 & 0,714 & \\
\hline PSOC-PL 9 & 0,614 & \\
\hline PSOC-PL 5 & 0,584 & \\
\hline PSOC-PL 2 & 0,572 & 0,422 \\
\hline PSOC-PL 8 & 0,546 & \\
\hline PSOC-PL 16 & 0,538 & 0,464 \\
\hline PSOC-PL 14 & 0,518 & \\
\hline PSOC-PL 6 & & 0,735 \\
\hline PSOC-PL 7 & & 0,670 \\
\hline PSOC-PL 11 & & 0,618 \\
\hline PSOC-PL 13 & & 0,599 \\
\hline PSOC-PL 15 & & 0,580 \\
\hline PSOC-PL 10 & & 0,540 \\
\hline PSOC-PL 17 & & 0,536 \\
\hline \multicolumn{3}{|l|}{ PSOC-PL 1} \\
\hline \multicolumn{3}{|l|}{ PSOC-PL 12} \\
\hline Procent wyjaśnianej wariancji & $30,50 \%$ & $8,76 \%$ \\
\hline $\begin{array}{l}\text { Skumulowany procent } \\
\text { wyjaśnianej wariancji }\end{array}$ & \multicolumn{2}{|c|}{$39,26 \%$} \\
\hline
\end{tabular}

Źródło: opracowanie własne. 
Analiza zgodności zewnętrznej dla powyższego rozwiązania dwuczynnikowego przyniosła satysfakcjonujące, wyższe niż poprzednio, współczynniki rzetelności. I tak współczynnik alfa Cronbacha dla podskali Satysfakcja wyniósł 0,80, dla podskali Skuteczność 0,78 oraz dla całego narzędzia - 0,86.

Trafność konwergencyjną polskiej wersji narzędzia oszacowano poprzez analizę związków między jego wynikami a wynikami ogólnymi uzyskanymi za pomocą Kwestionariusza Poczucia Stresu (KPS) (Plopa, Makarowski, 2010) oraz Edynburskiej Skali Depresji Poporodowej (EPDS) (Cox, Holden, Sagovsky, 1987). Jak już wspomniano w niniejszym artykule, wcześniejsze badania dowodzą, że zarówno stres, jak i depresja pozostają w istotnych związkach z poczuciem kompetencji u rodziców (Caldwell i in., 2011; Kohlhoff, Barnett, 2013).

Wyniki ogólne Skali Poczucia Kompetencji Rodzicielskich oraz dla podskal Satysfakcja i Skuteczność korelują istotnie z wynikami ogólnymi KPS (współczynniki korelacji rho-Spearmana wynoszą kolejno: $\mathrm{r}=-0,581, \mathrm{p}<0,01$; $\mathrm{r}=-0,593, \mathrm{p}<0,01 ; \mathrm{r}=-0,411, \mathrm{p}<0,01)$ oraz EPDS $(\mathrm{r}=-0,582, \mathrm{p}<0,01$; $\mathrm{r}=-0,580, \mathrm{p}<0,01 ; \mathrm{r}=-0,417, \mathrm{p}<0,01)$. Korelacje te nie są silne, jednak ich kierunek jest ujemny, co jest zgodne z założeniami, że większy stres i obecność objawów depresyjnych negatywnie wpływają tak na ogólne poczucie kompetencji rodzicielskich, jak i jego wymiary, tj. obniżają poczucie satysfakcji z bycia rodzicem i poczucie skuteczności w radzeniu sobie z obowiązkami wynikającymi $\mathrm{z}$ rodzicielstwa. Wyniki takie przemawiają za potwierdzeniem trafności adaptowanego narzędzia.

\section{DYSKUSJA}

Celem prezentowanych badań było oszacowanie wartości psychometrycznych polskiej wersji Parenting Sense of Competence Scale. Przeprowadzona analiza wskazuje, że narzędzie to charakteryzuje się zadowalającymi właściwościami psychometrycznymi, to znaczy jest rzetelne i trafne. Współczynniki rzetelności alfa Cronbacha są zadowalające i zbliżone do uzyskanych w oryginalnych badaniach Gibaud-Wallston i Wandersman (1978) oraz w badaniach walidacyjnych z udziałem matek niemowląt (Karp, Lutenbacher, Wallston, 2015). Wysoki współczynnik stabilności otrzymany w pomiarze test-retest podkreśla rzetelność narzędzia. Wyniki uzyskane w drugim pomiarze po upływie dwóch tygodni różnią się od siebie na poziomie istotności statystycznej, jednak sugeruje to jedynie trafność metody. Różnica ta oznacza prawdopodobnie wzrost umiejętności związanych z opieką nad dzieckiem, który wynika z coraz większego doświadczenia badanych matek. Można przypuszczać, że sam udział w badaniach (pomiar pierwszy) stał się dla nich okazją do refleksji nad poziomem dotychczasowych kompetencji czy też satysfakcji z troszczenia się o dziecko i zaspokajania jego potrzeb, co pozytywnie wpłynęło na radzenie sobie z wyzwaniami wynikającymi z macierzyństwa 
i znalazło swoje odzwierciedlenie w kolejnym badaniu (pomiar drugi). Również korelacje między wynikami dla polskiej wersji PSOC-PL i narzędziami do pomiaru stresu i objawów depresyjnych są zadowalające i potwierdzają dotychczasowe doniesienia (Begle, Dumas 2011; Caldwell i in., 2011; Bloomfield, Kendall, 2012; Kohlhoff, Barnett, 2013), a tym samym trafność adaptowanej skali. Przedstawione rezultaty pozwalają twierdzić, że PSOC-PL jest rzetelną i trafną metodą, którą można stosować zarówno w dalszych badaniach empirycznych, jak i do oceny nabywania kompetencji w procesie adaptacji do macierzyństwa (np. jako rezultat treningów kompetencji rodzicielskich albo wybranych elementów programu szkół rodzenia).

Przedstawione analizy nie są jednak wolne od ograniczeń, które w tym miejscu należy wymienić. Przede wszystkim trzeba zwrócić uwagę na fakt, że Skala Poczucia Kompetencji Rodzicielskich jest jednym z częściej używanych w badaniach na świecie narzędziem do pomiaru kompetencji rodzicielskich. Tymczasem, chociaż ogólne właściwości psychometryczne polskiej wersji językowej są zadowalające, otrzymanie w wyniku zastosowanych analiz statystycznych wersji skróconej o kilka pozycji uniemożliwia zastosowanie Skali w badaniach międzykulturowych. Brakuje również miary kontrolnej względem pomiaru poczucia skuteczności u badanych matek. W dalszych badaniach warto uzupełnić ten brak, wykorzystując do pomiaru trafności np. Skalę Uogólnionej Własnej Skuteczności (Generalized Self-Efficacy Scale - GSES) R. Schwarzera i M. Jerusalema w polskiej adaptacji Z. Juczyńskiego (2001b). Wątpliwości może również budzić krótki, dwutygodniowy odstęp pomiędzy pomiarami względnej stabilności metodą test-retest. Czas trwania tego odstępu nie został jasno określony w literaturze przedmiotu, przyjmuje się jednak, że w zależności od przedmiotu pomiaru jest to okres od kilku tygodni do kilku miesięcy. Jankowski i Zajenkowski (2009) uznają, że krótszy odstęp czasowy może być zalecany np. w przypadku pomiaru postawy, dłuższy - w odniesieniu do cech (np. temperamentu) i jako przykład podają badanie stabilności bezwzględnej polskiej wersji kwestionariusza CISS (Coping Inventory of Stressful Situations) (Strelau, Jaworowska, Wrześniewski, Szczepaniak, 2005) w odstępie 2-3 tygodni pomiędzy pomiarami. Inną słabością prezentowanych badań jest zawężenie badanej populacji do matek małych dzieci, co - mimo iż spójne z zamysłem pierwotnym Autorów i badaniami oryginalnymi - uniemożliwia uniwersalne wykorzystanie narzędzia. Zasadne wydaje się powtórzenie badań walidacyjnych z udziałem bardziej licznej, a przede wszystkim zróżnicowanej ze względu na staż rodzicielski i płeć, populacji.

Podsumowując, można stwierdzić, że polska wersja językowa Parenting Sense of Competence Scale (PSOC) jest narzędziem o satysfakcjonujących właściwościach psychometrycznych, jednak jej przydatność tak do celów naukowych, jak i praktycznych wymaga dalszej weryfikacji. 


\section{BIBLIOGRAFIA}

Argyle M. (2004). Psychologia szczęścia. Wrocław: Wydawnictwo Astrum

Bandura A. (1977). Self-efficacy: Toward a unifying theory of behavioural change. Psychological Review, 84, 191-215

Bandura A. (1997). Self-Efficacy: The Exercise of Control. New York, NY: W. H. Freeman and Company

Beck C. T., Indman P. (2005). The many faces of postpartum depression. Journal of Obstetrics and Gynecology Neonatal Nursing, 34 (5), 569-576

Begle A. M., Dumas J. E. (2011). Child and parental outcomes following involvement in a preventive intervention: Efficacy of the PACE program. The Journal of Primary Prevention, 32, 67-81. doi: 10.1007/s10935-010-0232-6

Bloomfield L., Kendall S. (2012). Parenting self-efficacy, parenting stress and child behavior before and after a parenting programme. Primary Health Care Research \& Development, 13, 364-372. doi: $10.1017 / \mathrm{S} 1463423612000060$

Caldwell J. G., Shaver P. R., Li C.-S., Minzenberg M. J. (2011). Childhood maltreatment, adult attachment, and depression as predictors of parental self- efficacy in at-risk mothers. Journal of Aggression, Maltreatment and Trauma, 20, 595-616. doi: 10.1080/10926771.2011.595763

Coleman P. K., Karraker K. H. (2000). Parenting self-efficacy among mothers of school-age children: Conceptualization, measurement, and correlates. Family Relations, 49 (1), 13-24. doi: 10.1111/j.1741-3729.2000.00013.x

Cox J. L., Holden J. M., Sagovsky R. (1987). Detection of postnatal depression. Development of the 10-item Edinburgh postnatal depression scale. British Journal of Psychiatry, 150, 782-786

Czapiński J. (2004). Psychologia pozytywna. Warszawa: Wydawnictwo Naukowe PWN

Czub M. (2003). Znaczenie wczesnych więzi społecznych dla emocjonalnego rozwoju dziecka. Forum Oświatowe, 2 (29), 31-49

Diener E., Lucas R. E., Oishi S. (2002). Subjective well-being: The science of happiness and life satisfaction. W: C. R. Snyder, S. J. Lopez (eds.), Handbook of positive psychology (s. 63-73). Oxford: Oxford University Press

Gibaud-Wallston J. (1977). Self-esteem and situational stress factors related to sense of competence in new parents. Unpublished doctoral dissertation, University of Rhode Island, Providence

Gibaud-Wallston J., Wandersman L. P. (1978). Development and utility of the parental sense of competence. Paper presented at the meeting of the American Psychological Association, Toronto

Gilmore L., Cuskelly M. (2009). Factor structure of the Parenting Sense of Competence Scale using a normative sample. Child: Care, Health and Development, 35 (1), 48-55. doi:10.111 $1 / \mathrm{j} .1365-2214.2008 .00867$

Jackson A. P. (2000). Maternal self-efficacy and children's influence on stress and parenting among single black mothers in poverty. Journal of Family Issues, 21, 3-16. doi:10.1177/019251300021001001

Jankowski K., Zajenkowski M. (2009). Metody szacowania rzetelności testu. W: Psychometria podstawowe zagadnienia (s. 84-110). Warszawa: Vizja Press

Johnston C., Mash E. J. (1989). A measure of parenting satisfaction and efficacy. Journal of Clinical Child Psychology, 18 (2), 167-175. doi: 10.1207/s15374424jccp1802_8

Jones T., Prinz R. J. (2005). Potential roles of parental self efficacy in parent and child adjustment: A review. Clinical Psychology Review, 25 (3), 341-363. doi: 10.1016/j.cpr.2004.12.004

Juczyński Z. (2000). Poczucie własnej skuteczności - teoria i pomiar. Acta Universitatis Lodziensis. Folia Psychologica, 4, 11-24

Juczyński Z. (2001a). Narzędzia pomiaru w promocji i psychologii zdrowia. Warszawa: Polskie Towarzystwo Psychologiczne 
Juczyński Z. (2001b). Zachowania zdrowotne i wartościowanie zdrowia. W: Narzędzia pomiaru w promocji i psychologii zdrowia (s. 112-122). Warszawa: Pracownia Testów Psychologicznych

Karp S. M., Lutenbacher M., Wallston K. A. (2015). Evaluation of the Parenting Sense of Competence Scale in Mothers of Infants. Journal of Child and Family Studies, 24 (11), 3474-3481. doi: 10.1007/s10826-015-0149-z

Kohlhoff J., Barnett B. (2013). Parenting self-efficacy: Links with maternal depression, infant behaviour and adult attachment. Early Human Development, 89, 249-256. doi:10.1016/j.earlhumdev.2013.01.008

Nunes C., Jiménez L., Menéndez S., Ayala-Nunes L., Hidalgo V. (2016). Psychometric properties of an adapted version of the parental sense of competence (PSOC) scale for Portuguese at-risk parents. Child \& Family Social Work, 21, 433-441. doi: 10.1111/cfs.12159

Plopa M., Makarowski R. (2010). Kwestionariusz Poczucia Stresu. Warszawa: Vizja Press \& It.

Raikes H. A., Thompson R. A. (2005). Efficacy and social support as predictors of parenting stress among families in poverty. Infant Mental Health Journal, 26 (3), 177-190. doi:10.1002/ imhj.20044

Shumow L., Lomax R. (2002). Parental self-efficacy: predictor of parenting behaviour adolescent outcomes. Parenting, Science and Practice, 2, 127-150. doi: 10.1207/S15327922PAR0202_03

Teti D. M., Gelfand D. M. (1991). Behavioural competence among mothers of infants in the first year: The mediational role of maternal self-efficacy. Child Development, 62, 918-929. doi: 10.1111/j.1467-8624.1991.tb01580.x

Walęcka-Matyja K., Kurpiel D. (2015). Satysfakcja z życia a poczucie skuteczności i styl wychowania w percepcji matek młodzieży z niepełnosprawnością. Psychologia Rozwojowa, 20 (1), 75-89. doi:10.4467/20843879PR.15.004.3476

Veenhoven R. (1991). Questions on happiness: Classical topics, modern answers, blind spots. W: F. Strack, M. Argyle, N. Schwarz (eds.), Subjective well-being. An interdisciplinary perspective (s. 7-26). Oxford-Toronto: Pergamon Press

Karolina KossakowsKa

\section{PSYCHOMETRIC PROPERTIES AND CHARACTERISTICS OF POLISH ADAPTATION OF THE PARENTING SENSE OF COMPETENCE SCALE (PSOC-PL) - FEMALE VERSION}

\footnotetext{
Abstract. To evaluate psychometric properties of the Polish version of the Parenting Sense of Competence Scale (PSOC-PL) by Johnston and Mash for measuring parental competences in mothers of children under 2 years old.

The Parenting Sense of Competence Scale is a self-assessment method. It consists of 17 statements which allow to assess general scores on parental competences as well as each of the two dimensions: Satisfaction and Self-Efficacy. The study was conducted in a group of 251 women with children under 24 months of age. The mean age of the participants was 29,35 years (SD =4,57). The Edinburgh Postnatal Depression Scale and the Sense of Stress Questionnaire were used additionally to assess validity of the Polish version of the adapted tool.

PSOC-PL is a reliable and valid tool. The factor structure is similar to the original one - as a result of the conducted analysis, there was obtained the 15-item version of PSOC, which has a two-factor structure - factor I: Satisfaction and factor II: Self-Efficacy. The results obtained in
} 
PSOC-PL in the current study show statistically significant correlations with level of stress and intensity of depressive symptoms.

The results of the reliability of PSOC-PL do not differ from the results obtained in the original and other validation studies all over the world. The Polish version of the tool meets the basic psychometric criteria and can be used to assess competence of mothers of young children.

Keywords: parental competences, satisfaction, self-efficacy, validation, PSOC - Polish version. 